\title{
Pengembangan Aplikasi Mobile Vote Berbasis Android untuk Umum
}

\author{
Nabilla Risma Aulia*, Estu Sinduningrum, \& Atiqah Meutia Hilda. \\ Program Studi Teknik Informatika, Fakultas Teknik, \\ Universitas Muhammadiyah Prof. DR. HAMKA, Jakarta. \\ Jl. Tanah Merdeka no.6 Pasar Rebo Jakarta Timur \\ Telp. +62-21-87782739, Fax. +62-21-87782739 \\ Email : nabilla.risma.aulia@gmail.com
}

\begin{abstract}
Abstrak - Proses pemilihan pimpinan lembaga yang dilakukan melalui pemungutan suara masih banyak menggunakan cara manual, dan mengharuskan datang ke lokasi pemilihan serta belum memanfaatkan teknologi digital. Cara tersebut membutuhkan waktu pemungutan, dan menunggu hasil perhitungan suara yang lama. Beberapa aplikasi sebelumnya pengguna tidak bisa membuat voting dan admin harus memasukkan data pengguna baru. Oleh karena itu diperlukan pengembangan agar dapat berjalan lebih efektif dan efisien. Metode pendekatan sistem menggunakan waterfall dan UML (Unified Modeling Language) sebagai desain perancangannya. Pengembangan aplikasi m-voting ini dapat digunakan dalam berbagai kategori pemilihan, pengguna dapat mengatur kandidat yang diinginkan sehingga menghasilkan hasil voting yang diinginkan. Aplikasi ini dapat diakses melalui mobile sehingga memudahkan pengguna melakukan voting berdasarkan waktu dan keberadaan tempa. Hasil survey tingkat kepuasan yang dicapai pengguna sebesar 89,75\% merasa aplikasi dapat berjalan dengan baik daripada sistem sebelumnya.
\end{abstract}

Kata kunci : M-Voting, pemilihan, kandidat, dan mobile.

\section{Pendahuluan}

Di era saat ini kebutuhan penggunaan telepon seluler (ponsel) semakin meningkat di kalangan masyarakat. Perkembangan ponsel berbasis android sangatlah pesat, hal ini terbukti dari banyaknya produksi ponsel berbasis android. Pada umumnya masyarakat menggunakan ponsel untuk berbagai jenis kegiatan seperti berkirim pesan, bermain game, hingga mencari informasi melalui internet dapat dilakukan melalui ponsel ini.

Dengan banyaknya pengguna ponsel di Indonesia, hal ini mengakibatkan segala aktifitas yang dilakukan semuanya menggunakan ponsel. Tetapi, masih banyak aktifitas yang belum menggunakan ponsel, contohnya dalam melakukan pemilihan umum. Pemilihan umum sekarang masih sering dilakukan dalam kehidupan sehari-hari,contohnya dalam pemilihan ketua kelas, pemilihan ketua RT atau RW, pemilihan ketua mahasiswa, sampai ke pemilihan presiden. Tetapi, pemilihan tersebut masih bersifat manual, yang artinya masih mengguunakan kertas dan menghitung suara satu persatu. Lain halnya dengan pemilihan ketua mahasiswa atau pemilihan walikota dan lain sebagainya yang mengharuskan datang menuju TPS yang sudah disediakan, menunjukkan kartu identitas, menuju bilik suara, dan mencoblos calon yang dipilih. Hal ini kurang efisien karena memerlukan dana yang besar untuk pembuatan kertas suara dan membeli tinta. Kemudian jika tidak bisa menuju TPS karena terhalang oleh suatu hal yang mengakibatkan tidak bisa menyumbangkan hak suaranya. Banyak juga terjadi suara yang tidak sah karena mencoblos di luar kotak, atau mencoblos lebih dari satu kandidat dengan sengaja atau tidak sengaja, sehingga mengurangi jumlah suara yang ada.

Berdasarkan dari hasil kuesioner online, $70 \%$ merasa bahwa membuang waktu harus datang ke TPS. 76\% merasa segan datang ke TPS. 66\% merasa proses pencoblosan melalui tahapan yang lama. $80 \%$ merasa pemilihan umum memerlukan biaya yang banyak. $78 \%$ merasa banyak suara kosong yang tidak sah, dan $87 \%$ setuju dibuatnya aplikasi mvoting ini.

Oleh karena itu, dengan banyaknya masalah yang timbul dari proses pemungutan suara secara manual dan hasil dari kuisioner tersebut, maka banyak gagasan yang muncul untuk menggantikan pemungutan suara secara manual dengan media digital dan diharapkan dapat menggantikan lebih baik dengan prioritas pemilu yang dilaksanakan dengan mudah, cepat, akurat, dan menghemat biaya. Berdasarkan hal-hal tersebut, maka penulis tertarik untuk mengangkat masalah tentang pembuatan aplikasi m-voting yang dapat membantu mahasiswa dalam proses pemilihan umum. Maka penulis bermaksud menyusun skripsi ini dengan judul "PENGEMBANGAN APLIKASI MOBILE VOTE BERBASIS ANDROID UNTUK UMUM"

\section{Dasar Teori}

M-voting atau mobile voting adalah suatu sistem pemilihan yang dilakukan melalui sebuah ponsel. M-voting pada hakekatnya adalah pelaksanaan pemungutan suara yang 
dilakukan secara digital mulai dari proses pendaftaran pemilih, pelaksanaan pemilihan, pemungutan suara, dan pengiriman hasil suara. Penerapan m-voting diharapkan dapat mengatasi permasalahan yang timbul dari pemilu yang diadakan secara konvensional. Kondisi penerapan dan teknologi m-voting terus berubah seiring perkembangan teknologi informasi yang sangat cepat. Kendala-kendala mvoting yang pernah terjadi di berbagai negara yang pernah dan sedang menerapkannya menjadi penyempurnaan $\mathrm{m}$ voting selanjutnya. Salah satu segi positif dari penerapan mvoting saat ini adalah bisa dilakukan di ponsel masingmasing dan perangkat lunak yang digunakan membuat mvoting makin murah dari waktu ke waktu dan untuk perangkat lunak makin terbuka untuk diaudit secara bersama. [1]

Unified Modelling Language (UML) adalah sebuah bahasa yang berdasarkan grafik/gambar untuk memvisualisasi, menspesifikasikan, membangun, dan pendokumentasian dari sebuah sistem pengembangan software berbasis OO (ObjectOriented). UML sendiri juga memberikan standar penulisan sebuah sistem blue print, yang meliputi konsep bisnis proses, penulisan kelas-kelas dalam bahasa program yang spesifik, skema database, dan komponen-komponen yang diperlukan dalam sistem software. [2]

Android adalah software untuk perangkat mobile yang mencakup sistem operasi, middleware dan aplikasi kunci. Pengembangan aplikasi pada platform Android menggunakan bahasa pemrograman Java. Serangkaian aplikasi inti Android antara lain klien email, program SMS, kalender, peta, browser, kontak, dan lain-lain. Dengan menyediakan sebuah platform pengembangan yang terbuka, pengembang Android menawarkan kemampuan untuk membangun aplikasi yang sangat kaya dan inovatif. Pengembang bebas untuk mengambil keuntungan dari perangkat keras, akses informasi lokasi, menjalankan background services, mengatur alarm, tambahkan pemberitahuan ke status bar, dan banyak lagi. Android bergantung pada versi Linux 2.6 untuk layanan sistem inti seperti keamanan, manajemen memori, manajemen proses, network stack, dan model driver. Kernel juga bertindak sebagai lapisan abstraksi antara hardware dan seluruh software stack.[3]

HTML (HyperText Markup Language) adalah bahasa standar yang digunakan untuk membuat website sedangkan CSS adalah bahasa yang digunakan untuk mendesain tampilan website.

Xampp adalah software yang digunakan untuk mengelola SQL. Xampp juga bisa digunakan sebagai web server. Xampp menggunakan beberapa bahasa pemograman khusus yakni, PHP, MySQL dan Perl.

\section{Metodologi Penelitian}

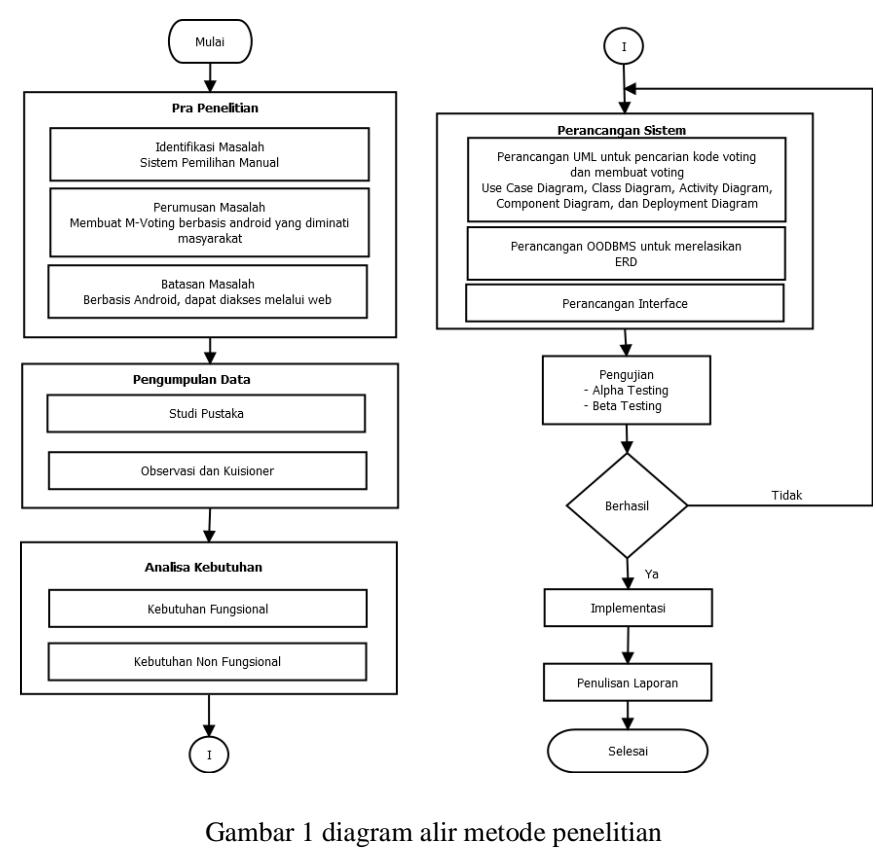

Pra Penelitian. mengidentifikasi masalah-masalah yang ada berdasarkan latar belakang masalah, merumuskan masalahmasalah penelitian yang akan diselesaikan dan membatasi masalah-masalah yang akan dibahas agar lebih fokus dan sesuai dengan tujuan penelitian. Identifikasi masalah, rumusan masalah, dan batasan masalah tersebut telah diuraikan pada bab 1.

Pengumpulan Informasi. Pengumpulan informasi dilakukan dalam proses penelitian untuk memperkuat dan mempermudah penulis dalam melakukan perancangan. Adapun metode yang digunakan penuis dalam pengumpulan informasi yaitu :

a. Studi Pustaka. Penulis mengumpulkan data dengan menggunakan media-media terutama buku dan pencarian data menggunakan internet yang berkaitan dengan skripsi ini.

b. Observasi. Penulis akan melakukan pengamatan untuk mendapatkan data-data yang diperlukan dalam skripsi.

c. Kuesioner. kuesioner dilakukan pada saat sebelum dan sesudah penelitian. Peneliti akan memberikan kuisioner kepada beberapa mahasiswa yang pernah terlibat dalam pemilihan untuk mendapatkan informasi data yang diperlukan. Kemudian peneliti akan memberikan kuisioner di akhir penelitian untuk mendapatkan data yang sesuai dengan tujuan penelitian

Analisis Kebutuhan. Analisis dibagi menjadi 2 yaitu kebutuhan fungsional dan kebutuhan non fungsional.

\section{a. Kebutuhan Fungsional}

Dalam analisis kebutuhan sistem fungsional ini, sistem menyediakan form pendaftaran untuk calon pemilih, sistem dapat menampilkan data diri dan visi misi dari para kandidat, sistem dapat menunjukkan hasil voting secara langsung dan cepat, dan sistem tidak hanya digunakan satu kali pemilihan, tetapi bisa diganti dengan pemilihan yang lainnya. 


\section{b. Kebutuhan Non Fungsional}

Analisis kebutuhan non fungsional adalah, sistem dapat di akses melalui internet dan aplikasinya hanya dapat dijalankan pada smartphone berbasis Android, sistem harus memastikan bahwa data pemilih yang diinputkan dalam form valid, dan sistem memiliki tampilan (antar muka) yang mudah dipahami.

Perancangan Sistem. Dalam perancangan sistem, aplikasi yang dibuat akan diuji cobakan di smartphone penulis. Sedangkan database aplikasi diletakkan di localhost komputer. Selanjutnya database aplikasi akan diletakkan di server independen yang dirancang supaya dapat diakses melalui jaringan internet.

\section{Perancangan UML}

Pada penelitian ini penulis merancang UML 5 diagram, yaitu Use Case Diagram, Class Diagram, Activity Diagram, Component Diagram, dan Deployment Diagram.

\section{Perancangan Database}

Database yang digunakan pada aplikasi ini yaitu MySQL yang terdiri dari beberapa tabel. Pada perancangan database ini menggunakan $E R D$.

\section{Perancangan Interface}

Pengujian. Setelah aplikasi sudah selesai dibuat, langkah selanjutnya adalah pengujian terhadap aplikasi. Pengujian aplikasi dilakukan untuk mengetahui apakah aplikasi yang telah dibuat sudah berjalan dengan benar atau belum. Dalam pengujian ini penulis melakukan dua macam pengujian, yaitu:

\section{a. Alpha Testing}

Pengujian dilakukan oleh orang-orang yang terlibat dalam pengembangan untuk menghilangkan beberapa masalah sebelum akhirnya sampai ke pengguna.

\section{b. Beta Testing}

Pengujian dilakukan oleh pengguna langsung untuk evaluasi, diberi kuisioner dan diberi nilai.

Implementasi .Tahap selanjutnya adalah implementasi. Pada tahap ini aplikasi yang sudah diuji coba akan diterapkan dan akan disebarkan aplikasinya dalam berbentuk .apk. maka aplikasi M-Voting bisa digunakan pada smartphone maupun website.

Penulisan. Dari tahapan penelitian mulai dari awal hingga akhir akan didokumentasikan secara tertulis. Tahap ini adalah tahapan terakhir dari penelitian.

\section{Temuan dan Pembahasan}

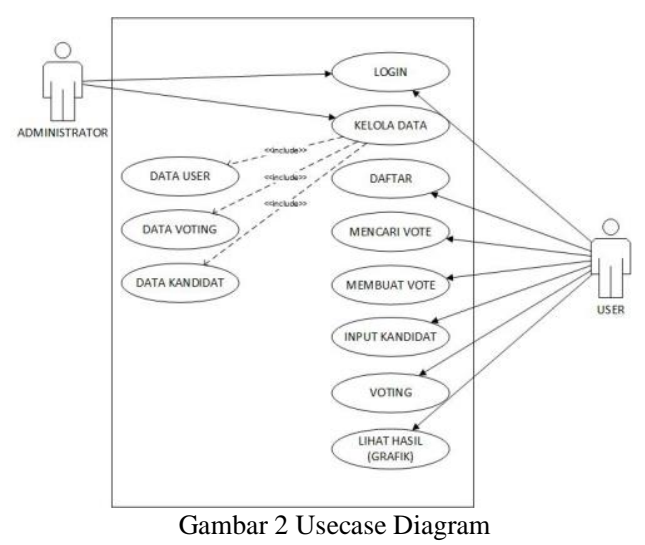

Use Case Diagram. Pada perancangan Use Case Diagram ini digunakan untuk memahami interaksi dan kegiatan antara pengguna dan sistem. Use Case digunakan untuk mengetahui fungsi apa saja yang ada di sebuah sistem dan siapa saja yang berhak menggunakan fungsi-fungsi tersebut. Use Case diagram menjelaskan urutan kegiatan yang dilakukan oleh administrator dan user, sebagai berikut:

\section{Daftar}

Daftar bertujuan untuk memasukan identitas pengguna. Tindakan yang dilakukan untuk daftar dapat dilihat pada tabel 1 .

\begin{tabular}{|c|l|}
\multicolumn{2}{c|}{ Tabel 1 Use Case Daftar } \\
\hline $\begin{array}{c}\text { Nama } \\
\text { Usecase }\end{array}$ & Daftar \\
\hline Aktor & User \\
\hline Deskripsi & Menginput identitas pengguna \\
\hline Alternatif & \multicolumn{1}{|c|}{-} \\
\hline Tindakan & $\begin{array}{l}\text { Memasukan nomor identitas } \\
\text { Memasukan username } \\
\text { Memasukan nama lengkap } \\
\text { Memasukan alamat email } \\
\text { Memasukan password }\end{array}$ \\
\hline $\begin{array}{c}\text { Tindakan } \\
\text { Akhir }\end{array}$ & $\begin{array}{l}\text { Sistem akan kembali ke halaman awal } \\
\text { untuk melakukan login terlebih dahulu }\end{array}$ \\
\hline
\end{tabular}

2. Login

Masuk ke aplikasi ke aplikasi voting berdasarkan tingkatan pengguna. Jika sebagai admin akan masuk ke laman admin, jika sebagai user akan masuk ke laman user. Tindakan yang dilakukan untuk login dapat dilihat pada tabel 2.

Tabel 2 Usecase login

\begin{tabular}{|l|l|}
\hline $\begin{array}{l}\text { Nama } \\
\text { Usecase }\end{array}$ & Login \\
\hline Aktor & Admin dan User \\
\hline Deskripsi & Masuk ke halaman laman utama \\
\hline Alternatif & $\begin{array}{l}\text { Jika belum memiliki username, user harus } \\
\text { daftar terlebih dahulu }\end{array}$ \\
\hline Tindakan & $\begin{array}{l}\text { Pilih login } \\
\text { Memasukan username. } \\
\text { Memasukan password. }\end{array}$ \\
\hline $\begin{array}{l}\text { Tindakan } \\
\text { Akhir }\end{array}$ & $\begin{array}{l}\text { Sistem akan menampilkan halaman yang } \\
\text { sesuai jika yang login user atau admin. Jika } \\
\text { admin, sistem akan menampilkan halaman } \\
\text { admin. Jika user, sistem akan menampilkan } \\
\text { halaman utama membuat voting }\end{array}$ \\
\hline
\end{tabular}

3. Mencari Vote

Mencari voting menggunakan kode unik voting, yang bertujuan untuk melakukan voting. Tindakan yang dilakukan untuk mencari voting dapat dilihat pada tabel 3 .

\begin{tabular}{|l|l|}
\hline $\begin{array}{l}\text { Nama } \\
\text { Usecase }\end{array}$ & Mencari Voting \\
\hline Aktor & User \\
\hline Deskripsi & Menginput kata kunci judul voting \\
\hline Alternatif & $\begin{array}{l}\text { Jika voting tidak ditemukan, maka voting } \\
\text { belum terdaftar. }\end{array}$ \\
\hline
\end{tabular}




\begin{tabular}{|l|l|}
\hline \multirow{3}{*}{ Tindakan } & $\begin{array}{l}\text { Pilih menu cari voting } \\
\text { Memasukan kata kunci judul voting yang } \\
\text { di dapat. } \\
\text { Jika voting masih berlaku, akan muncul } \\
\text { laman voting yang sesuai dengan kata } \\
\text { kunci tersebut. }\end{array}$ \\
\hline $\begin{array}{l}\text { Tindakan } \\
\text { Akhir }\end{array}$ & $\begin{array}{l}\text { Sistem akan menampilkan halaman untuk } \\
\text { voting }\end{array}$ \\
\hline
\end{tabular}

\section{Membuat Vote}

Membuat voting umum yang akan digunakan untuk pemilihan. Tindakan yang dilakukan untuk membuat dapat dilihat pada tabel 4 .

Tabel 4 usecase membuat voting

\begin{tabular}{|l|l|}
\hline $\begin{array}{l}\text { Nama } \\
\text { Usecase }\end{array}$ & Membuat Voting \\
\hline Aktor & User \\
\hline Deskripsi & Membuat voting umum \\
\hline Alternatif & - \\
\hline Tindakan & $\begin{array}{l}\text { Pilih menu buat voting } \\
\text { Masukan judul dan deskripsi voting }\end{array}$ \\
\hline $\begin{array}{l}\text { Tindakan } \\
\text { Akhir }\end{array}$ & $\begin{array}{l}\text { Jika sudah input, akan menampilkan } \\
\text { halaman untuk mengisi data kandidat }\end{array}$ \\
\hline
\end{tabular}

5. Input Kandidat

Memasukan data para kandidat seperti nama ketua dan wakil, tanggal ulang tahun, visi misi, dan foto. Tindakan yang dilakukan untuk input kandidat dapat dilihat pada tabel 5 .

\begin{tabular}{|c|c|}
\hline \multicolumn{2}{|r|}{ Tabel 5 Usecase input kandidat } \\
\hline $\begin{array}{l}\text { Nama } \\
\text { Usecase }\end{array}$ & Input Kandidat \\
\hline Aktor & User \\
\hline Deskripsi & Menginput data para kandidat \\
\hline Alternatif & Hanya bisa menginput 4 kandidat \\
\hline Tindakan & $\begin{array}{l}\text { a) Memasukan nama ketua } \\
\text { b) Memasukan nama wakil (optional) } \\
\text { c) Memasukan tanggal lahir ketua } \\
\text { d) Memasukan tanggal lahir wakil } \\
\text { (optional) } \\
\text { e) Memasukan visi dan misi (optional) } \\
\text { f) Memasukan foto kandidat }\end{array}$ \\
\hline $\begin{array}{l}\text { Tindakan } \\
\text { Akhir }\end{array}$ & $\begin{array}{l}\text { Jika data sudah terisi, sistem akan } \\
\text { menampilkan halaman generate kode unik } \\
\text { voting, yang nantinya kode unik voting } \\
\text { tersebut yang akan di share. }\end{array}$ \\
\hline
\end{tabular}

\section{Melakukan Voting}

Melakukan voting pada laman yang tersedia. Memilih kandidat yang diinginkan. Tindakan yang dilakukan untuk melakukan voting dapat dilihat pada tabel 6 .
Tabel 6 Usecase melakukan voting

\begin{tabular}{|l|l|}
\multicolumn{2}{l}{ Tabel 6 Usecase melakukan voting } \\
$\begin{array}{l}\text { Nama } \\
\text { Usecase }\end{array}$ & Melakukan Voting \\
\hline Aktor & User \\
\hline Deskripsi & Memilih kandidat yang diinginkan \\
\hline Alternatif & - \\
\hline Tindakan & $\begin{array}{l}\text { Memilih kandidat yang diinginkan } \\
\text { dengan cara mengklik kandidat tersebut. }\end{array}$ \\
\hline $\begin{array}{l}\text { Tindakan } \\
\text { Akhir }\end{array}$ & $\begin{array}{l}\text { Pengguna dapat memilih kandidat pada } \\
\text { halaman voting }\end{array}$ \\
\hline
\end{tabular}

7. Melihat Hasil Voting

Melihat hasil voting yang baru saja diikuti, berupa data grafik batang. Tindakan yang dilakukan untuk melihat hasil voting dapat dilihat pada tabel 7 .

\begin{tabular}{|l|l|}
\hline $\begin{array}{l}\text { Nama } \\
\text { Usecase }\end{array}$ & Melihat Hasil Voting \\
\hline Aktor & User \\
\hline Deskripsi & Melihat hasil voting berupa grafik \\
\hline Alternatif & $\begin{array}{l}\text { Jika sudah melakukan voting, bisa } \\
\text { langsung melihat hasil voting }\end{array}$ \\
\hline Tindakan & $\begin{array}{l}\text { Setelah melakukan voting, akan muncul } \\
\text { tombol untuk lihat hasil } \\
\text { Setelah di klik, akan masuk ke laman } \\
\text { yang menunjukan hasil voting tersebut. }\end{array}$ \\
\hline $\begin{array}{l}\text { Tindakan } \\
\text { Akhir }\end{array}$ & $\begin{array}{l}\text { Sistem akan menampilkan hasil voting } \\
\text { berupa diagram batang. }\end{array}$ \\
\hline
\end{tabular}

\section{Kelola Data}

Kelola data untuk mengatur data user, data voting dan data kandidat. Kelola data bisa untuk menambahkan, menghapus, dan mengubah data yang diperlukan. Tindakan yang dilakukan untuk kelola data dapat dilihat pada tabel 8 .

Tabel 8 Usecase kelola data

\begin{tabular}{|c|c|}
\hline $\begin{array}{l}\text { Nama } \\
\text { Usecase }\end{array}$ & Kelola Data \\
\hline Aktor & Admin \\
\hline Deskripsi & $\begin{array}{l}\text { Menambah, menghapus, dan mengubah } \\
\text { data user, voting, dan kandidat. }\end{array}$ \\
\hline Alternatif & - \\
\hline Tindakan & $\begin{array}{l}\text { Login sebagai admin } \\
\text { Admin dapat menambah, menghapus dan } \\
\text { mengubah data dari user, voting dan } \\
\text { kandidat } \\
\text { Admin dapat menonaktifkan voting yang } \\
\text { sudah tidak berlaku. }\end{array}$ \\
\hline $\begin{array}{l}\text { Tindakan } \\
\text { Akhir }\end{array}$ & $\begin{array}{l}\text { Administrator dapat melihat, mengubah, } \\
\text { dan menghapus data pengguna. }\end{array}$ \\
\hline
\end{tabular}

Class diagram digunakan untuk menampilkan kelaskelas yang ada pada suatu sistem yang nantinya akan digunakan. Berikut merupakan class diagram dari sistem yang dirancang beserta struktur dan deskripsi class nya pada gambar 3, 


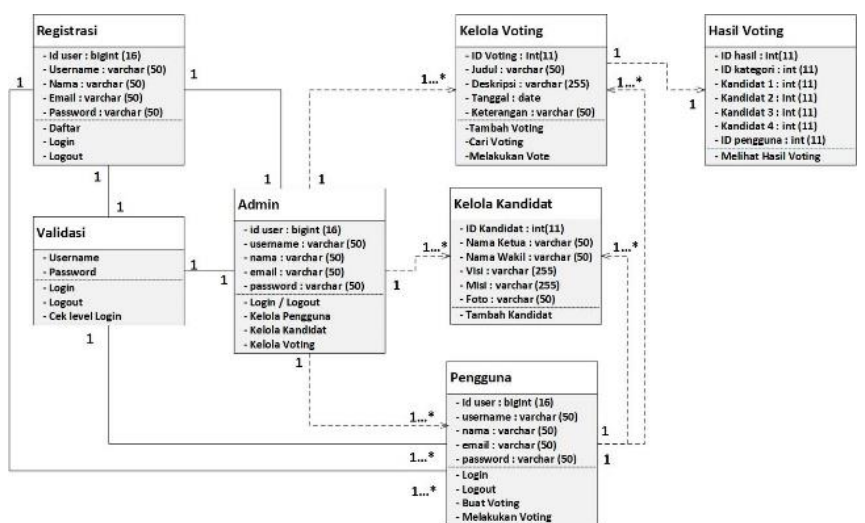

Gambar 3 Class Diagram Sistem Voting

Implementasi Software dan Hardware. Analisa dan perancangan yang dipaparkan pada bab sebelumnya telah menjelaskan bahwa aplikasi m-voting berjalan pada sistem browser dan android. Proses pembuatan aplikasi memerlukan beberapa software dan hardware. Software yang digunakan seperti Notepad++, browser Opera, dan Xampp untuk perancangan aplikasi websitenya, sedangkan Appgeyser untuk perancangan aplikasi androidnya.

Proses Dasar Aplikasi. Pada tahapan ini, dasar dari proses pembuatan aplikai dan pengoperasiannya sudah dijelaskan pada bab 4. Berjalannya aplikasi ditentukan dengan beberapa hal yaitu pembuatan database, pembuatan antarmuka, serta pembuatan aplikasi android.

Pembuatan Database. Pembuatan database dilakukan menggunakan localhost PHPMyAdmin. Kode pembuatan database ditulis menggunakan PHP.

Pembuatan Antarmuka. Pembuatan user interface web dilakukan menggunakan Notepad++ dan Xampp dengan menggunakan bahasa pemograman HTML, CSS dan PHP. Pada pengimplementasian antarmuka ini menggunakan web browser dan localhost.

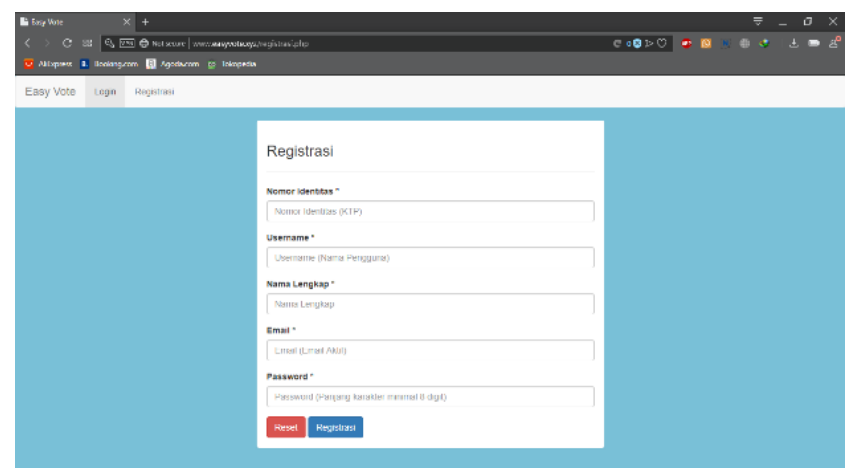

Gambar 4 Halaman registrasi website

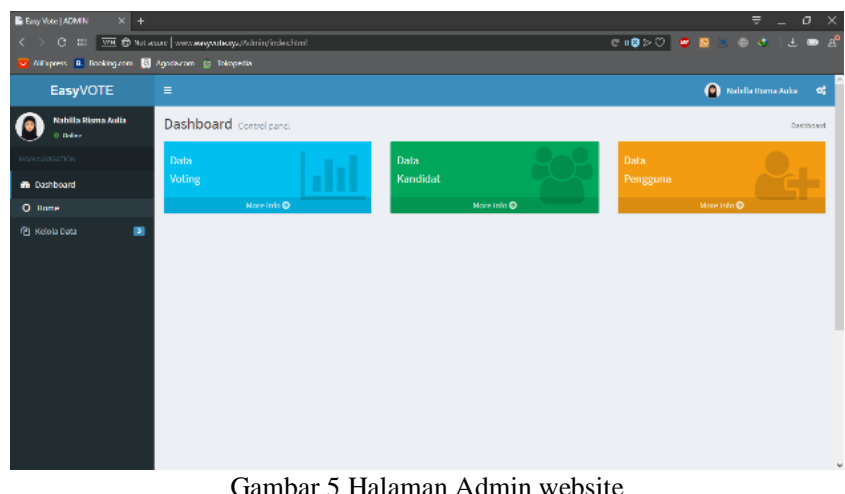

Gambar 5 Halaman Admin website

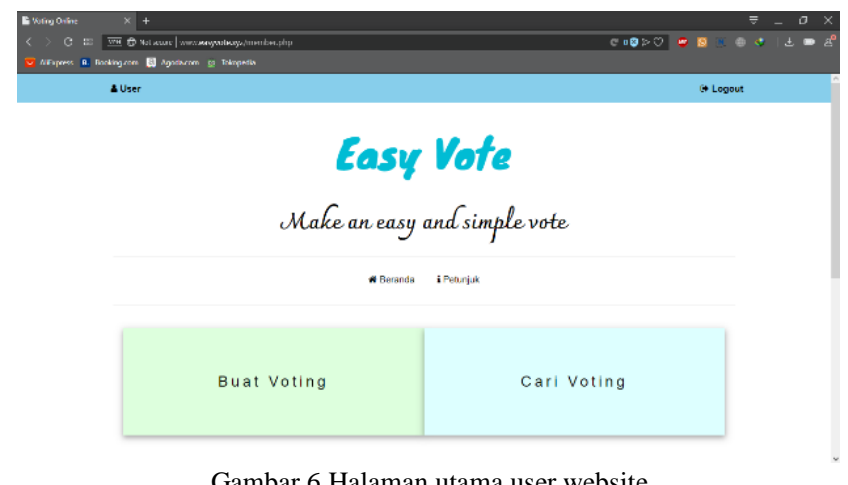

Gambar 6 Halaman utama user website

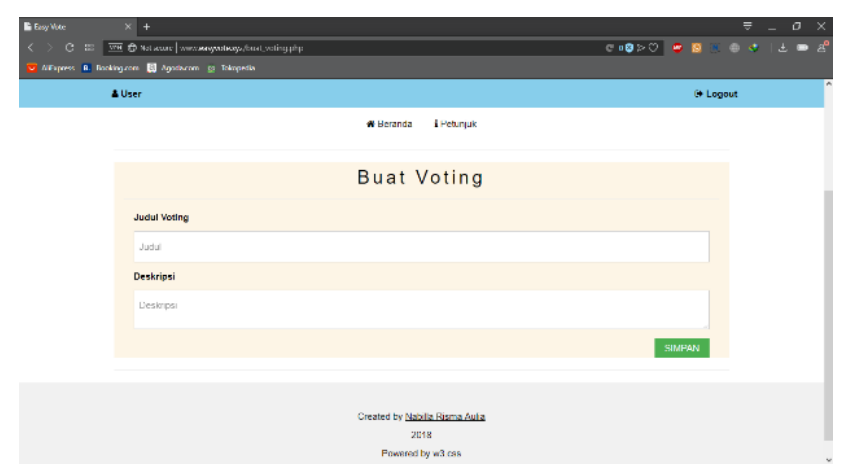

Gambar 7 Halaman buat voting website

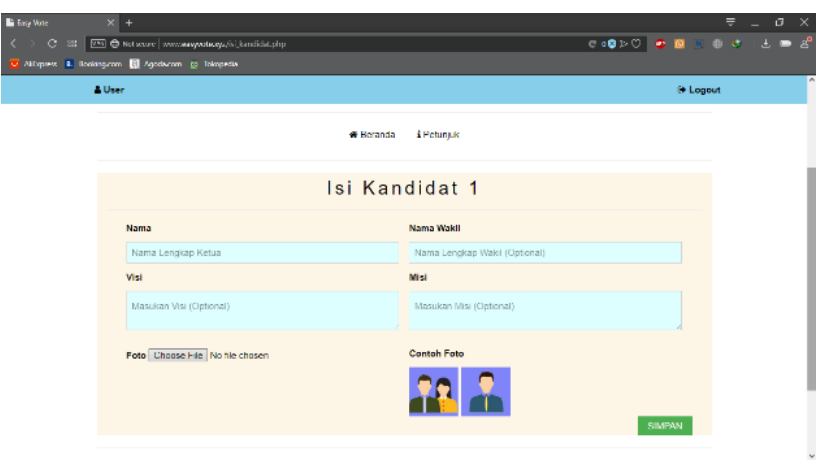

Gambar 8 Halaman isi kandidat website 


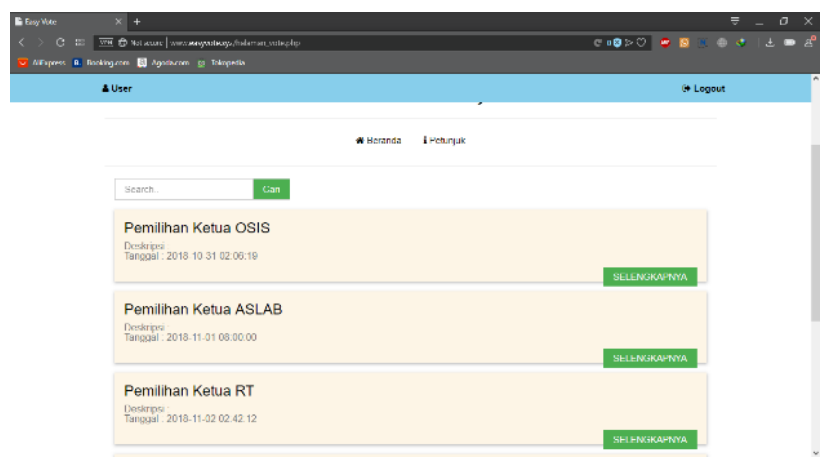

Gambar 9 Halaman cari voting website
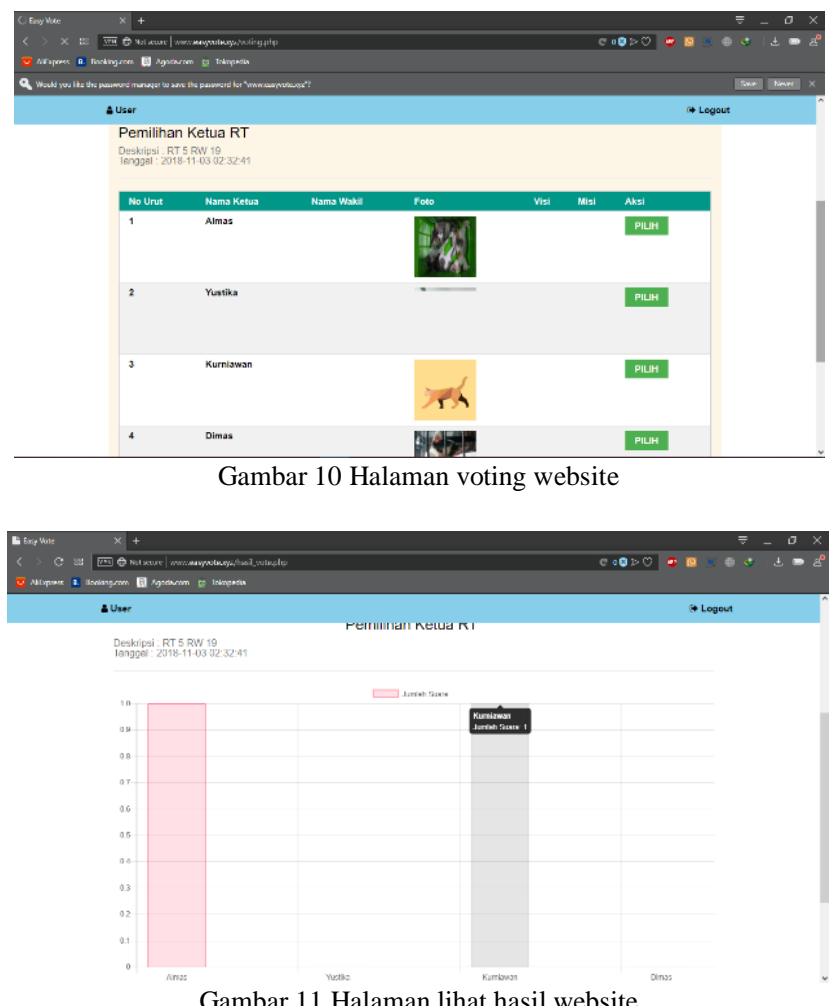

Gambar 11 Halaman lihat hasil website

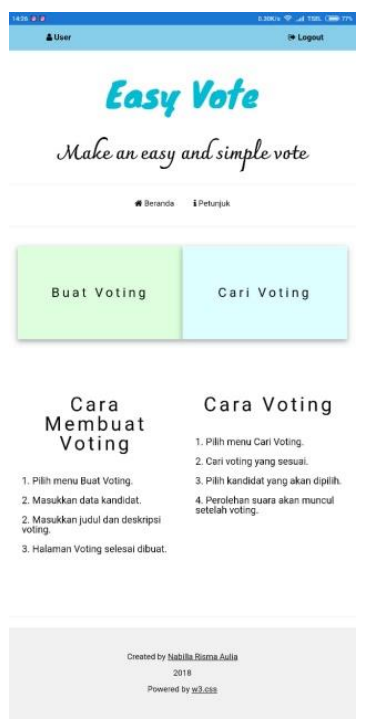

Gambar 12 Halaman utama user mobile

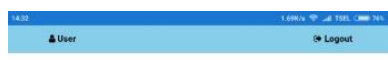

\section{Easy Vote}

Make the easy and simple vote

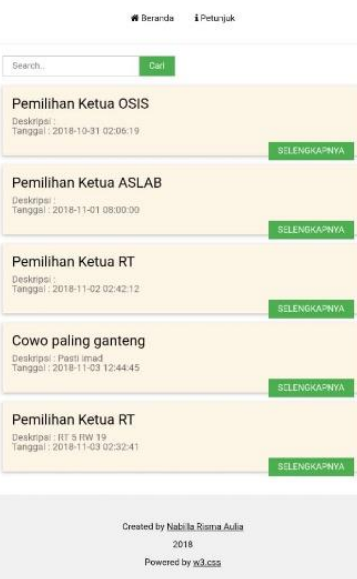

Gambar 13 Halaman cari voting mobile

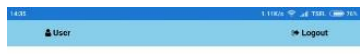

Easy Vote

Makethe easy and simple vote

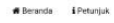

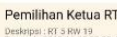

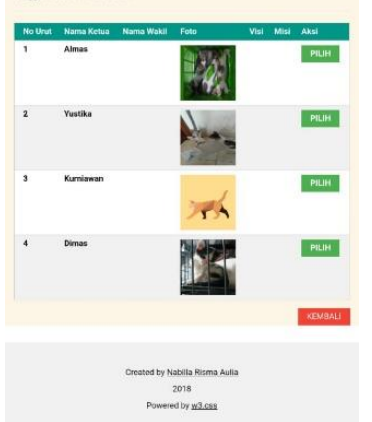

Gambar 14 Halaman voting mobile

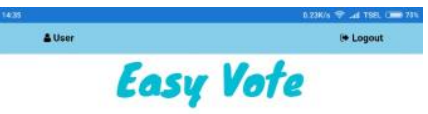

Make the easy and simple vote

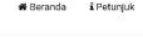

Pemilihan Ketua RT

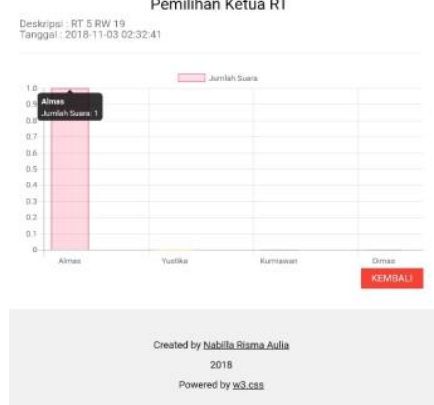

Gambar 15 Halaman lihat hasil mobile 


\section{Simpulan}

Berdasarkan hasil pembahasan dan pengujian aplikasi Mvoting yang dilakukan oleh penulis, maka terdapat beberapa hal yang dapat disimpulkan, yaitu :

1. Aplikasi m-voting ini dapat menjadi solusi dalam mengubah pemungutan suara secara manual menjadi digital, karena lebih efektif. Pernyataan ini berdasarkan hasil kuesioner akhir dari pertanyaan nomor 3 sebesar 93\%.

2. Aplikasi m-voting ini mudah dalam melakukan pemilihan karena tata cara yang dijelaskan mudah dimengerti serta aplikasi ini mudah diakses melalui browser ataupun mobile yang terkoneksi dengan internet. Pernyataan ini berdasarkan dari kuesioner akhir dari pertanyaan nomor 1 sebesar $90 \%$.
3. Aplikasi m-voting dapat berjalan dengan lancar dengan pengembangan yang dilakukan adalah pengguna dapat mendaftarkan diri sendiri dan membuat voting sendiri.

\section{Kepustakaan}

[1] Centinkaya, O., \& Centinkaya, D. (2007). Verification and Validation Issues in Electronic Voting. The Electronic Journal of e Government, 5(2), 117 - 126 diakses pada tanggal 9 Febuari 2018) Melalui http://samafon91.blogspot.com/

[2] Pressman, Roger S. 2012. Rekayasa Perangkat Lunak - Buku Satu, Pendekatan Praktisi (Edisi 7). Yogyakarta: Andi (diakses pada tanggal 14 Mei 2018) dari http://www.pengetahuandanteknologi.com

[ 3 ] Fowler, Martin, UML Distilled Edisi 3. Yogyakarta: Andi, 2005

[4] Gary B, S., Thomas J, C., \& Misty E, V. (2007). Discovering Computers : Fundamentals, 3thed. (Terjemahan), Jakarta: Salemba Infotek (diakses pada tanggal 9 Februari 2018) dari http://www.sribd.com

[5] Vikram Vaswani : MySQL Database Usage \& Administration, McGraw-Hill 20 